\title{
Suitability of aluminum material on sugar industry wastewater with chemical and electrochemical treatment processes
}

\author{
Omprakash Sahu ${ }^{1}$
}

Received: 28 April 2018 / Accepted: 11 November 2019 / Published online: 20 November 2019

(c) The Author(s) 2019

\begin{abstract}
Aluminum is a valuable material, which can be used for water and wastewater treatment. It exists in metal as well as in salt form. The efficiency of water and wastewater treatment depends upon the technology applied to treat. Sugarcane industry is coming under those industries which have a large amount of freshwater and release large amount of effluent. The goal of this research work is to study the behavior of aluminum metal and salt for the treatment of sugar industry wastewater on chemical oxidation and electrochemical oxidation. The effect of $\mathrm{pH}$, dosing, temperature and catalysis on metal and salt has been also studied with both treatment methods. The results show that maximum $90 \%$ of chemical oxygen demand and $94 \%$ of color removal can be achieved with an aluminum electrode (electrocoagulation) at optimum conditions, $\mathrm{pH} 7$, current density $178 \mathrm{~A} / \mathrm{m}^{2}$, electrode distance $20 \mathrm{~mm}$, and salt solution $0.5 \mathrm{M} \mathrm{NaCl}$. In the same way, $81 \%$ chemical oxygen demand and $85 \%$ color removal were achieved with alum for the $0.5 \mathrm{M}$ lime solution, at $50 \mathrm{mM}$ mass loading, $21{ }^{\circ} \mathrm{C}$ operating temperature and optimum $\mathrm{pH}$ of 7 , respectively. The sludge generated after treatment was also analyzed with settling filtration, thermal, FTIR and SEM.
\end{abstract}

Keywords Anode material · Chemical oxygen demand $\cdot$ Effluent $\cdot$ Optimization $\cdot$ Sludge

\section{Introduction}

Aluminum is the most abundant metal and the third most abundant element in the earth's crust, after oxygen and silicon. It makes up about $8 \%$ by weight of the earth's solid surface and it never occurs as a free element in nature [55]. It is a light, conductive, corrosion-resistant metal with a strong affinity for oxygen. This combination of properties has made it a widely used material, with applications in the aerospace, architectural construction and marine industries, as well as in wastewater treatment [11]. The aluminum salts with chloride, nitrate and sulfate are highly soluble and form a range of dissolved species on contact with water. The fate and behavior of aluminum in the aquatic environment are very complex [15]. Aluminum speciation, which refers to the partitioning of aluminum among different physical and chemical forms, and aluminum solubility are affected by a wide variety of environmental parameters, including $\mathrm{pH}$,

Omprakash Sahu

ops0121@gmail.com

1 Department of Chemical and Petroleum Engineering, UIE, Chandigarh University, Gharuan, Mohali, India solution temperature, and dissolved organic carbon (DOC) content. Metals in solution may be present as dissolved complexes, as "free" or aquo ions, in association with particles, as colloids or as solids in the process of precipitation [19].

In wastewater treatment, it can be used as an electrode in the electrocoagulation method, chemical salt as coagulant and sludge as red mud [56]. Aluminum salts are widely used as coagulants in water treatment process due to the effectiveness in removing a broad range of impurities, including colloidal particles and dissolved organic substances $[54,60]$. The mode of action is generally explained in terms of two distinct mechanisms: charge neutralization of colloids by cationic hydrolysis products and incorporation of impurities in an amorphous hydroxide precipitate. The relative importance of these mechanisms depends on factors such as $\mathrm{pH}$ and dosage [48]. Alternative coagulants, based on pre-hydrolysed forms of aluminum are more effective than the traditional additives in many cases, but their mode of action is not completely understood, especially with regard to the role of charge neutralization and hydroxide precipitation. Electrocoagulation is another way to treat the water and wastewater in which aluminum is used as an electrode [32]. In the EC process, coagulation is generated in situ 
by electrolytic oxidation of an appropriate anode material [42]. During this process, charged ionic species are removed from wastewater by allowing it to react with an ion having opposite charge, or with flock metallic hydroxides generated within the effluent $[16,21]$.

Aluminum in form plate has been used to treat the textile industry wastewater [12], dye wastewater [30], heavy metal [23], sewage water [42], petrochemical wastewater [31], dairy wastewater [13], hospital wastewater [20], etc. and in form of salt for leachate [52], dairy wastewater [36], pesticide wastewater [57], and tannery wastewater [43]. Aluminum is easily available, economically fit and highly efficient as compared to other metals for industrial effluent and drinking water treatment [41]. Sugar industry is one major high amount water consumer and discharges large quantity of wastewater [38]. Hence, with this information, an experimental was conducted to treat the sugar industry effluent with aluminum salt and electrode.

The main aim of this research work is to evaluate the performance and effectiveness of aluminum (salt and electrodes) to treat the sugar industry wastewater by the chemical and electro-oxidation techniques. The experimental operating parameters, effect of initial $\mathrm{pH}$, current density applied, and distance between electrodes were scrutinized for sugar industry wastewater.

\section{Materials and methods}

\section{Materials}

The wastewater used for the experiments was arranged from Bhoramdev Sugar Industry Ltd., Kavardha (C.G.), India. The composition of effluent before and after treatment is reported in Table 1. Analytical grade chemicals from Merck Limited, Mumbai, India, were used for analysis. The

Table 1 Characteristic of sugar industry wastewater

\begin{tabular}{lll}
\hline S. no. & Characteristics & Quality \\
\hline 1 & Color & Dark yellow \\
2 & pH change & 5.5 \\
3 & COD & 3682 \\
5 & Phosphate & 5.9 \\
6 & Protein & 43 \\
7 & Total solid & 1287 \\
8 & Suspended solid & 340 \\
9 & Dissolved solid & 947 \\
10 & Chloride & 50 \\
11 & Hardness & 900 \\
\hline
\end{tabular}

Except color and $\mathrm{pH}$ all values are in $\mathrm{mg} / \mathrm{L}$ aluminum sheet was used as electrode and it was arranged from the local market.

\section{Experimental methods}

The complete setup of an experiment program is shown in Fig. 1. The batch electrocoagulation cell used in the experimental study was constructed of plexiglass and the configuration is given in Table 2. The electrode arrangement consisting of four aluminum plates was used to connect the parallel electrodes in a monopolar mode (anodes and cathodes are in parallel connection, the current is divided between all the electrodes in relation to the resistance of the individual cells). The electrodes were connected to a DC power supply. Suspensions were stirred using a magnetic stirrer adjusted to an optimal rate $(300 \mathrm{rpm})$ to attain the highest efficiency of turbidity removal. A digital thermometer (range $140{ }^{\circ} \mathrm{C}$ ) was employed to measure the temperature of the suspensions, respectively. The current that flows through the cell and the voltage across the electrodes were measured with an ammeter and a voltmeter, respectively. Before each electrocoagulation run, the electrodes were washed with $15 \% \mathrm{HCl}$ solution to remove surface grease, and impurities on the electrode surfaces were removed by means of dipping electrodes for $1 \mathrm{~min}$ in a normal water solution.

Coagulation method is carried out in Jar test apparatus $0.20 \mathrm{dm}^{3}$ of SIWW was taken in a $0.50-\mathrm{dm}^{3}$ glass beaker. The $\mathrm{pH}$ of the effluent was noted and the initial $\mathrm{pH}(\mathrm{pH} 0)$ was adjusted by adding aqueous $\mathrm{NaOH}(1 \mathrm{M})$ or $\mathrm{H}_{2} \mathrm{SO}_{4}$ (1 M) solution in the range of $\mathrm{pH} 2-10$. A known amount from 20 to $50 \mathrm{mM}$ of the coagulant was added to the effluent and flash-mixed for $5 \mathrm{~min}$ by a magnetic stirrer and, thereafter, slowly mixed for $30 \mathrm{~min}$. The effluent sample was

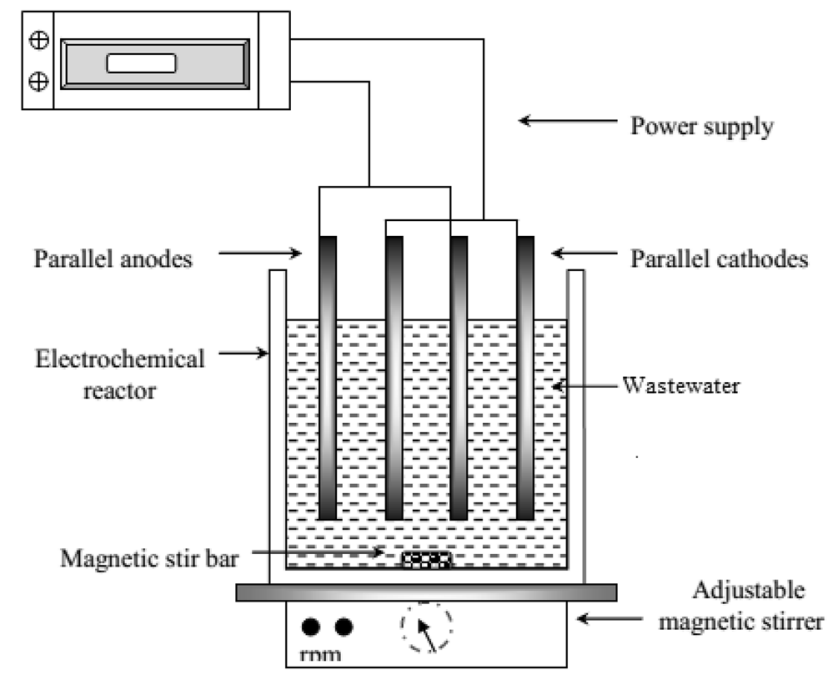

Fig. 1 Electrocoagulation experimental setup 
Table 2 Characteristics of EC (Al plate)

\begin{tabular}{lll}
\hline S. no. & & \\
Electrode & Material (anode and cathode) & Aluminum \\
1 & Shape & Rectangular may be square \\
2 & Size & $7.5 \mathrm{~cm} \times 7.5 \mathrm{~cm}$ \\
3 & Thickness & $2 \mathrm{~mm}$ \\
4 & Plate arrangement & Parallel \\
5 & Effective electrode surface area & $56.25 \mathrm{~cm}^{2}$ \\
6 & & \\
Reactor characteristics & Make & Perspex glass \\
1 & Reactor type & Batch mode \\
2 & Dimensions (cm) & $10.7 \times 10.7 \times 13.7$ \\
3 & Volume (dm $\left.{ }^{3}\right)$ & 1.5 \\
4 & Electrode gap & 20 mm \\
5 & Stirring mechanism & Magnetic bar \\
6 & & \\
Power supply & Voltage range & $0-30(\mathrm{~V})$ \\
1 & Current & $0-5($ A) \\
\hline
\end{tabular}

then taken in a glass cylinder and kept quiescent for $6 \mathrm{~h}$. The supernatant liquor was centrifuged and analyzed for its COD value. These steps were repeated at different dosages of the coagulant. The filtration characteristics of the solid residue formed in the treated effluent were studied using an ordinary zero haze grades.

\section{Analytical procedure}

The COD of the samples was determined by the standard dichromate reflux method [33]. The chloride concentration was determined by the standard titrimetric Volhard method [58]. Sulfates and the phosphates were determined using standard methods [33]. The concentrations of the metal ions in the filtrate and the residue were determined using an atomic absorption spectrometer (GBC, Model Avanta, Australia). The protein content was determined by the Bradford method [14]. The color of the sample was measured in terms of the absorbance at $\lambda=420 \mathrm{~nm}$ using a UV-Vis spectrophotometer (Model Lambda 35) from Perkin Elmer Instruments, Switzerland. The residual organics in the treated effluent were analyzed by Fourier transform infrared (FTIR) spectroscopy (Bruker Optics, VERTEX80). After the electrolysis experiment, the microstructure and thermal characteristics of the by-products, i.e., the sludge, were also examined by field emission scanning electron microscopy (FE-SEM, HITACHI, S-4700) and thermogravimetric analysis (TGA, SHIMADZU, DTG-60H). Filter paper (pore size 7-11 $\mu \mathrm{m}$ ) was supplied by S.D. Fine Chemicals Ltd. The filter paper was supported on a ceramic Buchner funnel and gravity filtration was carried out.

\section{Results and discussion}

\section{Reaction occurrences}

\section{Mechanism with metal}

Aluminum metal has been used as electrodes successfully in EC systems to treat water and wastewater. During electrochemical reactions, metal electrodes dissolved and form coagulant species with metal hydroxides [7]. Metal anode dissolution is accompanied by hydrogen gas evolution at cathodes, bubble capture and floating, and suspended solid formation, thus removing contaminants [8, 9]. When aluminum electrodes are used, the electrochemical reactions occurring are the following.

At the anode:

$\mathrm{Al}_{(\mathrm{s})} \rightarrow \mathrm{Al}_{(\mathrm{aq})}^{3+}+3 e^{-}$

At the cathode, depending on $\mathrm{pH}$ :

$2 \mathrm{H}_{2} \mathrm{O}_{(\mathrm{l})}+2 e^{-} \rightarrow \mathrm{H}_{2(\mathrm{~g})}+2 \mathrm{OH}_{(\mathrm{aq})}$,

$2 \mathrm{H}_{(\mathrm{aq})}+2 e^{-} \rightarrow \mathrm{H}_{2(\mathrm{~g})}$.

The generated $\mathrm{Al}_{(\mathrm{aq})}^{3+}$ ions combine with water and hydroxyl ions to form corresponding hydroxides and/or polyhydroxides as follows:

1. Monomeric species such as $\mathrm{Al}(\mathrm{OH})^{2+}, \mathrm{Al}(\mathrm{OH})_{2}^{+}$, and $\mathrm{Al}(\mathrm{OH})_{4}^{-}$by Eqs. 8, 9 and 10 .

2. Polymeric species such as $\mathrm{Al}_{2}(\mathrm{OH})_{2}^{4+}$ and $\mathrm{Al}(\mathrm{OH})_{5}^{2+}$. 
3. Amorphous and less soluble species such as $\mathrm{Al}(\mathrm{OH})_{3}$ by Eq. 11 and $\mathrm{Al}_{2} \mathrm{O}_{3}$.

$\mathrm{Al}^{3+}+\mathrm{H}_{2} \mathrm{O} \rightarrow \mathrm{Al}(\mathrm{OH})^{2+}+\mathrm{H}^{+}$,

$\mathrm{Al}(\mathrm{OH})^{2+}+\mathrm{H}_{2} \mathrm{O} \rightarrow \mathrm{Al}(\mathrm{OH})_{2}^{+}+\mathrm{H}^{+}$,

$\mathrm{Al}(\mathrm{OH})_{2}^{+}+\mathrm{H}_{2} \mathrm{O} \rightarrow \mathrm{Al}(\mathrm{OH})_{3}+\mathrm{H}^{+}$

$\mathrm{Al}(\mathrm{OH})_{3}+\mathrm{H}_{2} \mathrm{O} \rightarrow \mathrm{Al}(\mathrm{OH})_{4}^{-}+\mathrm{H}^{+}$.

Considering only mononuclear specification, the concentration of the various $\mathrm{Al}$ forms present in solution was calculated by Holt et al. [34] depending on $\mathrm{pH}$. Al complexes acting as coagulants are adsorbed on oil particles and thus neutralize the colloidal charges, resulting in destabilization of the emulsion. This phenomenon is similar to the action of chemical coagulants in conventional chemical treatment. Hydrogen bubbles formed at the cathode can adsorb on the flocculated species and induce their flotation. The bubbles formed also reduce fouling of the cathode surface which could occur due to the formation of deposits. Sometimes, $\mathrm{NaCl}$ is usually employed to increase the conductivity of the water or the wastewater to be treated. The presence of the chloride ion in solution has been reported to decrease passivation of the aluminum surface and thereby increase the efficiency of electrocoagulation processes [35]. The chloride ion has been attributed a role in the pitting corrosion of the metal surface.

\section{Mechanism with salt}

In aluminum derivatives, alum $\left(\mathrm{Al}_{2}\left(\mathrm{SO}_{4}\right)_{3} \cdot \mathrm{nH}_{2} \mathrm{O}\right)$ is a cheap and regular salt, and widely used as a coagulant in water and wastewater treatment. The aqueous chemistry of aluminum is complex and upon the addition of an aluminum coagulant in water treatment, multiple reaction pathways are possible. The type of interactions between the chemical coagulant and contaminants determines the mechanism of coagulation. The predominance mechanisms observed during conventional coagulation with metal coagulants are adsorption charge neutralization and sweep coagulation. For aluminum salts, the mechanism of coagulation is controlled by the hydrolysis species [22]. The positively charged polyhydroxy complexes such as $\left[\mathrm{Al}_{8}(\mathrm{OH})_{20}\right]^{4+}$ in the $\mathrm{pH}$ range between 4 and 7 are the effective flocculants. Oversaturation and formation of amorphous hydroxide precipitate $\left[\mathrm{Al}(\mathrm{OH})_{3}\right](\mathrm{s})$ enmesh colloidal particles in a "sweep floc". Many other monomeric and polymeric species reported are

Monomers:

$[\mathrm{Al}(\mathrm{OH})]^{2+},\left[\mathrm{Al}(\mathrm{OH})_{2}\right]^{+},\left[\mathrm{Al}_{2}(\mathrm{OH})_{2}\right]^{4+}$, and $\left[\mathrm{Al}(\mathrm{OH})_{4}\right]^{-}$. Polymers:
$\left[\mathrm{Al}_{6}(\mathrm{OH})_{15}\right]^{3+},\left[\mathrm{Al}_{7}(\mathrm{OH})_{17}\right]^{4+},\left[\mathrm{Al}_{8}(\mathrm{OH})_{20}\right]^{4+}$, and $\left[\mathrm{Al}_{13}(\mathrm{OH})_{34}\right]^{5+}$.

The alum as the coagulant is capable of achieving significant organic removal. The $\mathrm{pH}$ of the water during coagulation has profound influences on the effectiveness of coagulation for organic removal. Organic removal is much better in slightly acidic condition. For water of higher organic content, the optimum $\mathrm{pH}$ is displaced to slightly more acidic values.

\section{Effect of initial pH on COD and color removal}

To examine effects of the initial $\mathrm{pH}$ on COD and color reduction of wastewater, the experiment was carried out at initial COD $3682 \mathrm{mg} / \mathrm{l}, \mathrm{CD} 78 \mathrm{~A} / \mathrm{m}^{2}$ time $120 \mathrm{~min}$ and ED $20 \mathrm{~mm}$ as shown in Fig. 2a, b. It is seen that COD and color reduction were increased with increase in $\mathrm{pH}$, after certain optimum $\mathrm{pH}$ decrease. It is found that when $\mathrm{pH}$ is $2,4,6,7$, 8 , and 10 , the COD reduction was $32.1 \%, 45 \%, 53.1 \%, 60 \%$, $51.2 \%, 41.9 \%$ and color reduction $43 \%, 54 \%, 57 \%, 67 \%$, $64 \%, 49 \%$, respectively. From results, the maximum and minimum reductions were found at $\mathrm{pH}$, and $\mathrm{pH} 2$ and 10 . It might because aluminum ions may be found in different forms and phases, depending on the $\mathrm{pH}$ and chemical characteristics of the solution [24]. At pH values less than 4, aluminum ions that are released from electrodes can be found in the form $\mathrm{Al}\left(\mathrm{H}_{2} 0\right)_{6}^{3+}$, while, at a $\mathrm{pH}$ range of 5-6, aluminum may be in the forms $\mathrm{Al}(\mathrm{OH})^{2+}$ and $\mathrm{Al}(\mathrm{OH})^{2+}$. When the $\mathrm{pH}$ rises to higher values (5.5-8), aluminum changes to the form $\mathrm{Al}(\mathrm{OH})_{3}$, which means more removal of pollutant and stability; $\mathrm{pH}$ values greater than 8 may cause a dissolution of aluminum as ions again and decrease the removal efficiency. Based on the effect of $\mathrm{pH}$ on the chemical form of aluminum, it is expected that electrocoagulation efficiency would be dependent on $\mathrm{pH}$, to some extent $[26,41]$.

The efficiency of alum coagulant in the treatment of SIWW was also tested at different $\mathrm{pH}$ values. It was observed that with increase in $\mathrm{pH}$ from $\mathrm{pH} 2$ to $7, \mathrm{COD}$ reduction increased to $23 \%, 36 \%, 47 \%, 55 \%, 64 \%$ and $70 \%$ while color reduced to $24 \%, 40 \%, 50 \%, 58 \%, 69 \%$, and $75 \%$ at $\mathrm{pH} 2,3,4,5,6$, and 7 , respectively. The maximum COD and color reduced to $70 \%$ and $75 \%$ at $\mathrm{pH} 7$. When process was carried out from $\mathrm{pH} 8$ to 10 , the COD reduced to $67 \%, 65 \%$, and $60 \%$ and color reduced to 66,61 , and 59\%, respectively, at $\mathrm{pH} \mathrm{8,9}$ and 10 as shown in Fig. 2c, d. The aluminum cation compound reacts with negatively charged colloid of wastewater and neutralized it. Impurities and colloids can be adsorbed onto the hydroxide precipitate. The colloids present in the solution can be either entrapped inside the hydroxide flocs formed, or enmesh to the surface of hydroxides. The enmeshment is defined as sweep coagulation $[1-6,27]$. 

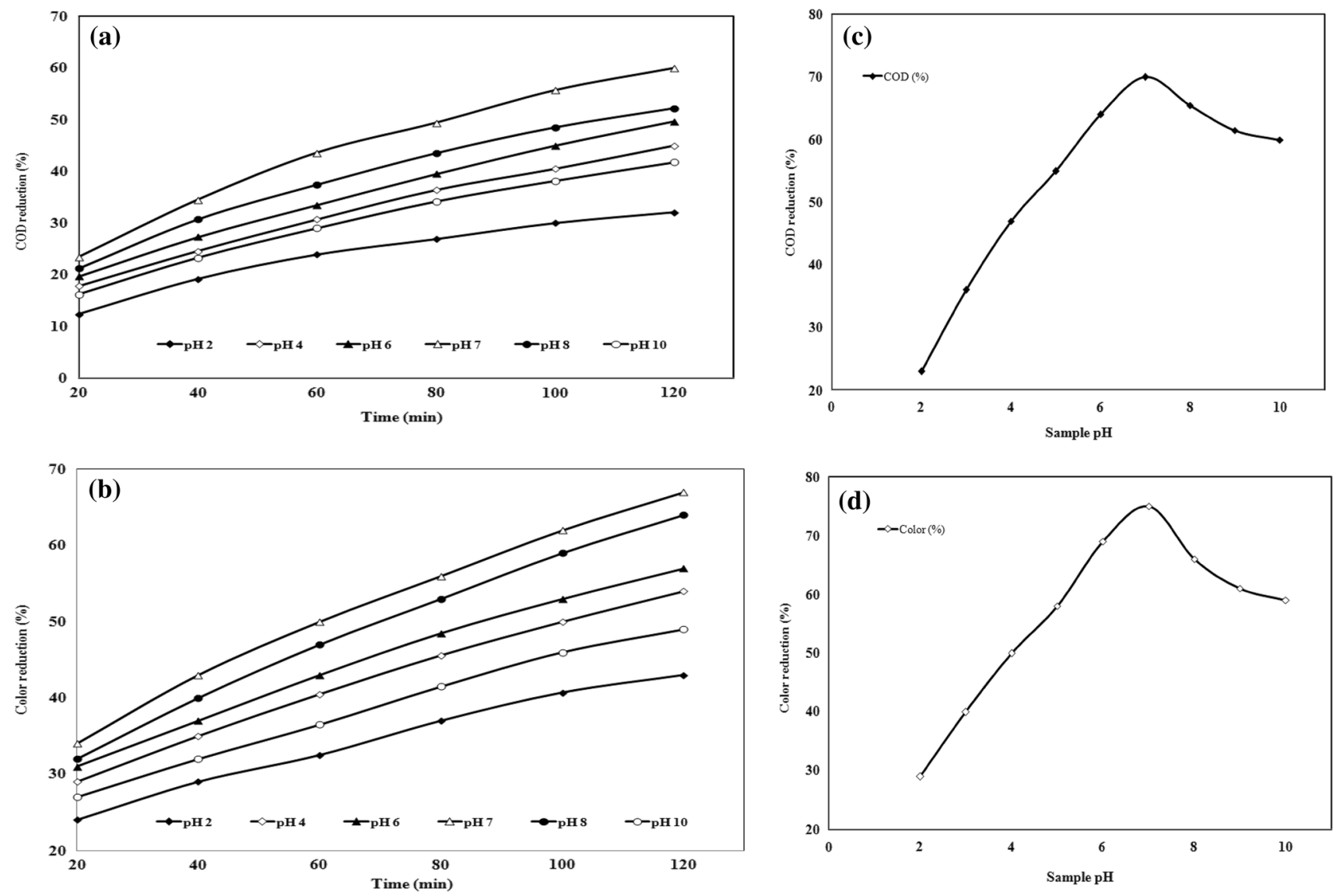

Fig. 2 Effect of $\mathrm{pH}$ on electrooxidation and chemical oxidation using aluminum electrode and salt. a COD, $\mathbf{b}$ color reduction CODo=3682 $\mathrm{mg} / \mathrm{l}$, $\mathrm{CD}=89 \mathrm{~A} / \mathrm{m}^{2}, \mathrm{ED}=20 \mathrm{~mm}, \mathrm{pHo}=5.5, \mathrm{To}=25^{\circ} \mathrm{C}, \mathbf{c} \mathrm{COD}, \mathbf{d}$ color reduction

\section{Effect of dosing (current density and mass loading)}

The effect of current density on COD and color removal efficiencies is depicted in Fig. 3a, b. It can be ascertained that the removal efficiency increases with applied current density. The removal efficiencies of COD were $52 \%, 60 \%, 69 \%, 79 \%$, and $74 \%$ and color reduction $64 \%, 67 \%, 73.5 \%$, and $8278 \%$ at $44.5 \mathrm{~A} / \mathrm{m}^{2}, 89 \mathrm{~A} / \mathrm{m}^{2}, 133.5 \mathrm{~A} / \mathrm{m}^{2}, 178 \mathrm{~A} / \mathrm{m}^{2}$ and $222.5 \mathrm{~A} /$ $\mathrm{m}^{2}$ of current densities, respectively. The effectiveness of current density on increasing removal efficiency slows down at higher current densities. The rate of anodic dissolution of aluminum is increased at higher current densities, resulting in a greater amount of coagulant and precipitant production. Consequently, this results in higher removal efficiency of organics. Bubble size decreases, while bubble generation rate increases with current density, which results in higher removal efficiency of organics via $\mathrm{H}_{2}$ flotation, in addition to the effect of coagulation $[50,53]$.

Available data indicate that the COD and color reduction efficiency increase from 68 to $78 \%$ and 70 to $82 \%$ by increasing the alum dose from 20 to $50 \mathrm{mM}$ shown in Fig. 3c, d. Further increase in dose decreased COD and color removal. The predominant removal mechanism at low doses of alum is adsorption and charge neutralization [37]. However, at high doses of coagulant is sweep floc coagulation by enmeshment in the aluminum hydroxide precipitate [59]. Further increase of the alum dose from 50 to $60 \mathrm{mM}$ decreases COD reduction by $78 \%$ and color reduction by $72 \%$, respectively. Therefore, the optimum dose of alum that enhanced maximum removal of COD and color was taken as $50 \mathrm{mM}$ [46].

\section{Effect of temperature}

The effect of current density on temperature change was carried out at different $\mathrm{CD}$ at $\mathrm{ED} 2 \mathrm{~cm}, \mathrm{pH} 7$ and reaction time from 20 to $120 \mathrm{~min}$, as shown in Fig. 4a. It was found that the temperature was $29,32,38,49,58$ and $65^{\circ} \mathrm{C}$ increase with an increase in time at $\mathrm{CD} 178 \mathrm{~A} /$ $\mathrm{m}^{2}$, respectively. The reason behind the increase in temperature is due to the breaking of a bond of pollutant and electric energy converted into heat energy. Temperature affects the floc formation, reaction rates and conductivity. As conductivity decreases temperature rises. Under 

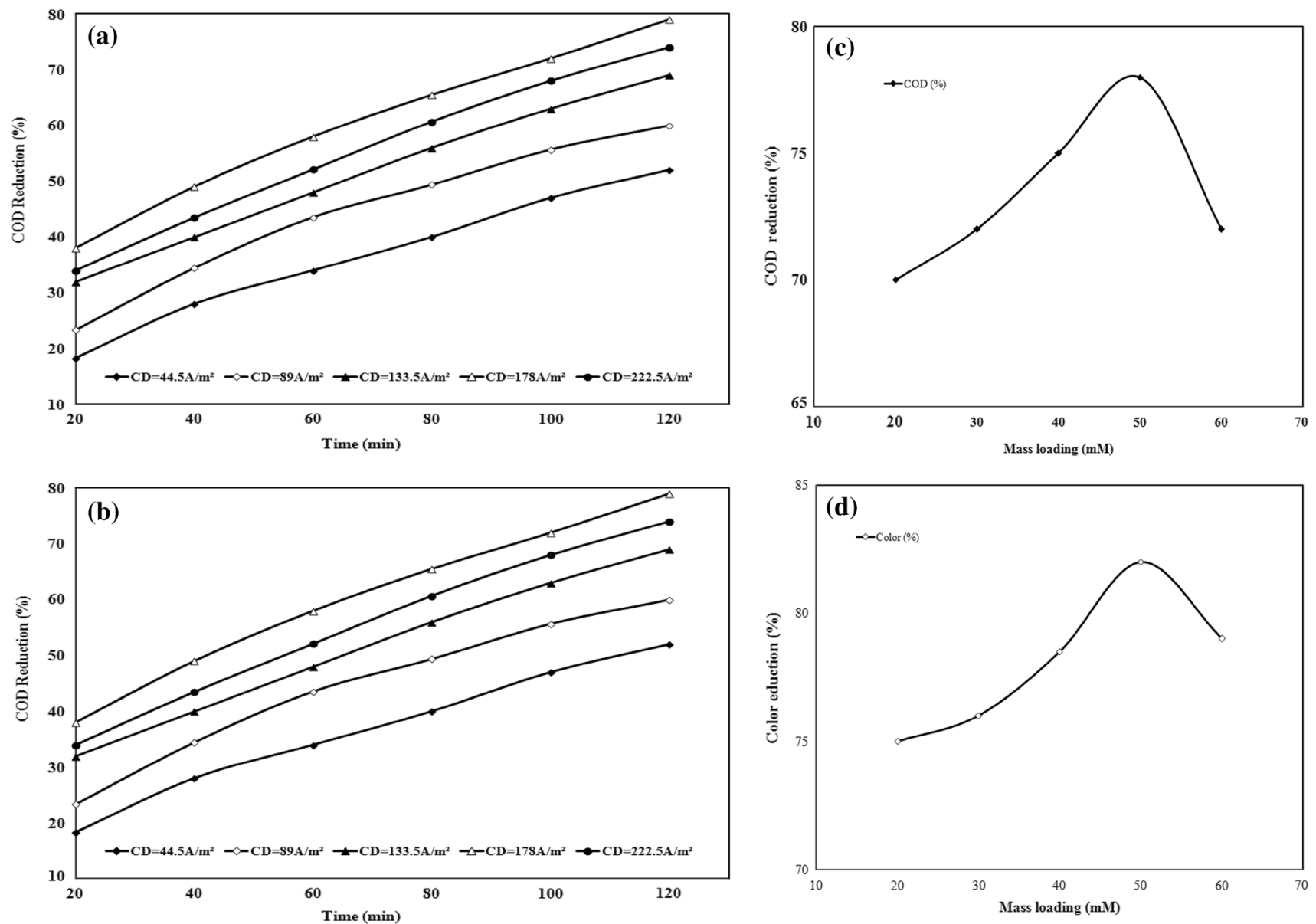

Fig. 3 Effect of current density and mass loading on electrooxidation and chemical oxidation processes using aluminum plate and salt. a COD, b color reduction $\mathrm{CODo}=3682 \mathrm{mg} / \mathrm{l}, \mathrm{ED}=20 \mathrm{~mm}, \mathrm{pH}=7, \mathbf{c} \mathrm{COD}$ and $\mathbf{d}$ color reduction

galvanostatic conditions, an increase in solution resistance leads to a higher voltage and thus greater power consumption $(V=I \times R)$. While current is set to drive constant, the voltage increases as resistance do, forcing the system to dissipate extra power $(P=V \times I)$ in the very same space mostly as heat, leading to a temperature increase. It has been suggested that when the temperature is too high, there is a shrinkage of large pores of the $\mathrm{Al}(\mathrm{OH})_{3}$ gel, which causes the formation of dense flocs that are more likely to deposit on the electrode surface $[17,18]$.

The effect of temperature also has been studied for coagulation, which is shown in Fig. 4b. The experiment was carried out at different temperatures from 15 to $31^{\circ} \mathrm{C}$. The result shows that at $21^{\circ} \mathrm{C}$ and $6 \mathrm{~h}$ retention time, $78 \%$ COD and $82 \%$ color reductions were found. The reduction of COD and color was deceased when at low temperature and high temperature of the sample. It may be because the variation of sample temperature during coagulation may lead to non-representative floc formation and the convection currents will interfere with settling [1-6, 27].

\section{Effect of catalyst}

To increase the reaction, catalyst has been used for both experiments. The effect of catalyst for electrocoagulation process at optimum condition was carried out which is shown in Fig. 5a. To examine the effect of a supporting electrolyte, electrocoagulation tests were conducted at two $\mathrm{NaCl}$ dosages $(0.3$, and $0.5 \mathrm{M})$ and compared with a test without the addition of $\mathrm{NaCl}$ at the same operational variables. Sodium chloride was selected because of its low toxicity at moderate levels, its reasonable cost, effective bactericidal action and the fact that the chloride species avoid inhibition phenomena at the surface of sacrificial anodes [25]. With the addition of $\mathrm{NaCl}$ salt in wastewater sample, it was observed that a maximum of $90 \%$ COD and $94 \%$ color reductions was found at $0.5 \mathrm{~m}$ catalysis loading at $120 \mathrm{~min}$ of electrolysis, which is high as compared to $0.3 \mathrm{M} \mathrm{NaCl}$ dose (84\% COD and $90 \%$ color) and without dosing (81\% $\mathrm{COD}$ and $84 \%$ color reduction) of $\mathrm{NaCl}$ salt. The addition of sodium chloride may often be necessary to increase the 

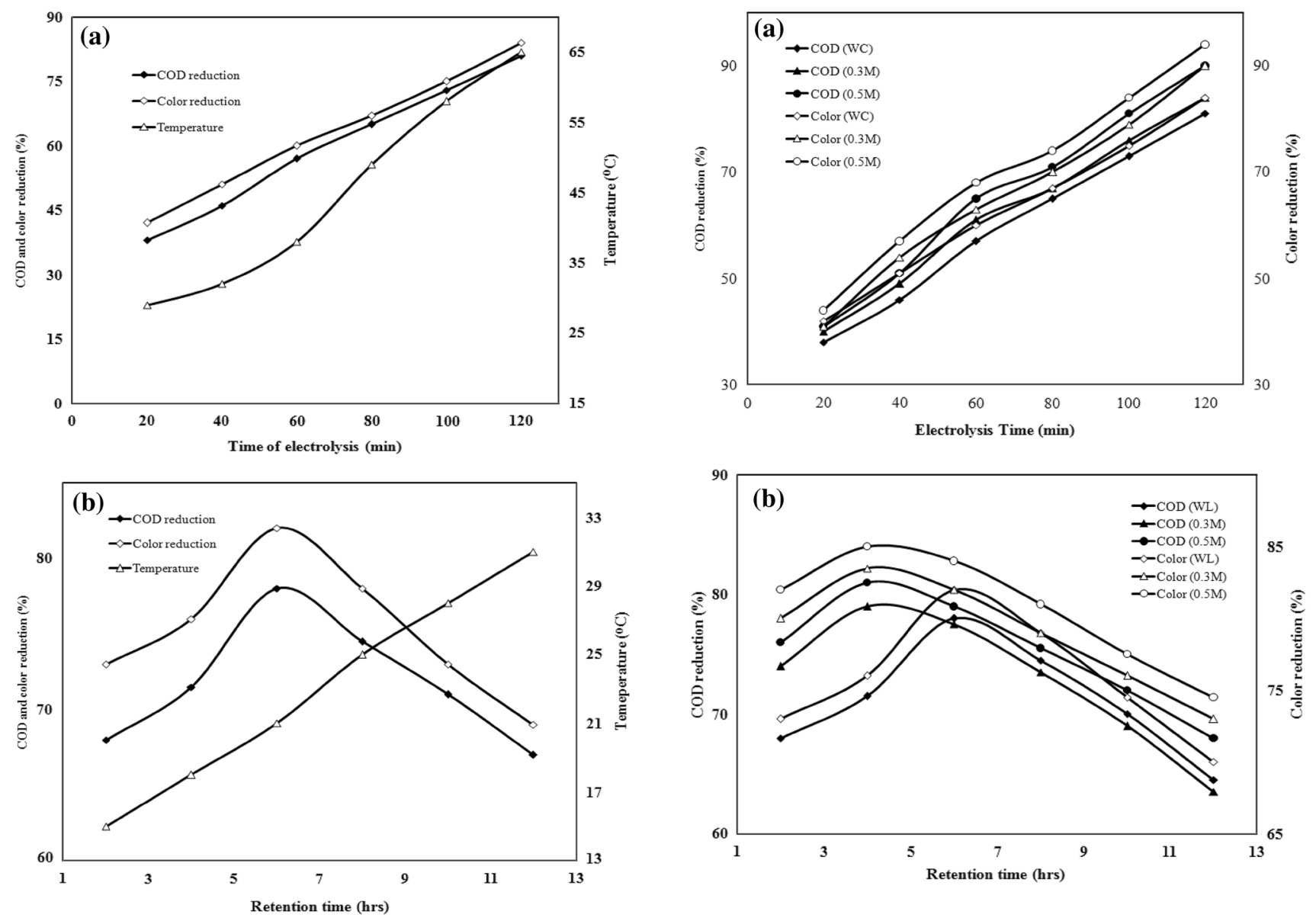

Fig. 5 Effect of catalysis on COD and color reduction at optimum loading and $\mathrm{pH}$ for a electrocoagulation, b coagulation processes using aluminum electrode and salt

g. 4 Effect of temperature on COD and color reduction at optimu loading and $\mathrm{pH}$ for a electrocoagulation, $\mathbf{b}$ coagulation processes using aluminum electrode and salt

electrical conductivity of the wastewater and to improve the performance and effectiveness of the electrochemical process $[40,49]$.

To examine the effect of catalyst for the coagulation process, lime was used at $0.3 \mathrm{M}$ and $0.5 \mathrm{M}$ of dosing, which is shown in Fig. 5b. Generally, lime is used for increasing or decreasing the $\mathrm{pH}$ of the wastewater as the acidic nature of alum always reduces the $\mathrm{pH}$ of sample and lime increases the $\mathrm{pH}[10]$. By this, combined effect of mass loading at $\mathrm{pH} 7$ was studied. The result shows that $81 \% \mathrm{COD}$ and $85 \%$ color reductions were found at $4 \mathrm{~h}$ of retention time as compared to without dosing of lime (73\% COD and 78\% color reductions at $6 \mathrm{~h}$ retention time) and $0.3 \mathrm{M}$ dosing lime (79\% COD and $83.5 \%$ color reductions). This attributes to alum, which reacts instantaneously and will proceed to other end products in the presence of lime. Lime also reduced the retention time for the coagulation process to $2 \mathrm{~h}$ as compared to without lime sample. Further increase in lime dose will decrease the COD and color reduction, due to an increase in $\mathrm{pH}$ of

the sample. In place of lime, caustic soda and soda ash are also used to improve the alkalinity in water treatment plant $[44,51]$.

\section{Sludge analysis}

\section{Settling}

The slurry obtained from EC treatment was subjected to sedimentation tests in a $0.5-\mathrm{dm}^{3}$ graduated glass cylinder. The time course of the settling of sludge for aluminum electrode and salt in terms of the dimensionless height of the solid-liquid interface $\left(\mathrm{H} / \mathrm{H}_{0}\right)$ is shown in Fig. 6. The Kynch theory was used to analyze the settling process [45]. The parameters such as sedimentation velocity $\left(u_{\mathrm{c}}\right)$, concentration $C(t)$, and the sedimentation flux were calculated. The sedimentation velocity $\left(u_{\mathrm{c}}\right)$ was found from the slope of the tangent at a given solid concentration, $C$. The concentration of sludge at time $t$ was determined using the following expression: 


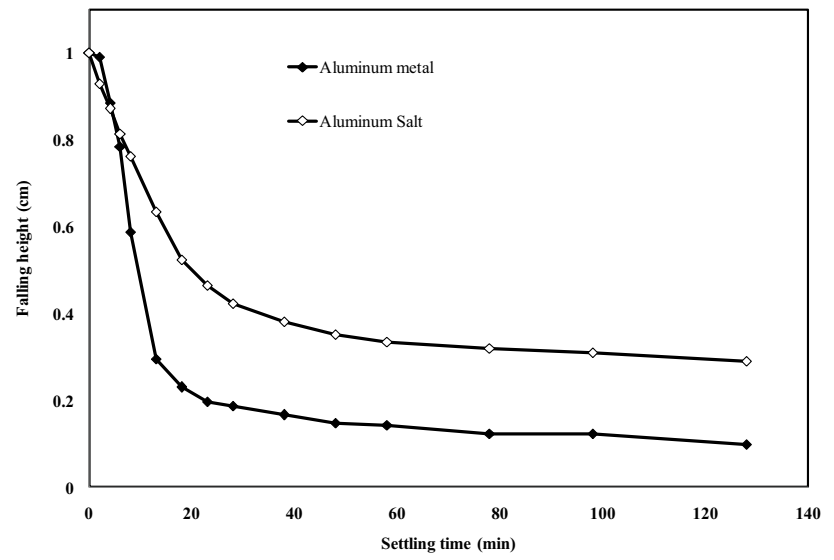

Fig. 6 Settlability of colloidal at optimum $\mathrm{pH}$ and loading on electrocoagulation and chemical coagulation processes using aluminum electrode alum salt

$C=\frac{C_{0} \times \text { Total height }}{\text { Height of suspension after time } t}$.

The value of $C_{\mathrm{u}}$, i.e., the concentration of the solids required in the underflow, for the treated effluent was found to be $75 \mathrm{~kg} / \mathrm{m}^{3}$. The maximum value of $\left[\left\{(1 / C)-\left(1 / C_{\mathrm{u}}\right)\right\} / u_{\mathrm{c}}\right]$ was found to be $4.54 \times 10^{3} \mathrm{~m}^{2} / \mathrm{kg} \mathrm{s}$. Using these values, the area of the sedimentation tank for any effluent flow rate thus can be calculated as follows:

$A=v_{\mathrm{f}} C_{0} \frac{\left(1 / C-1 / C_{\mathrm{u}}\right)}{u_{\mathrm{c}}}$,

where $v_{\mathrm{f}}$ volumetric flow rate of the effluent $\left(\mathrm{m}^{3} / \mathrm{s}\right)$ and $C_{0}$ the initial solid concentration $\left(\mathrm{kg} / \mathrm{m}^{3}\right)$.

From Fig. 6 it can be seen that the settling rate is very fast during the zone settling region for the aluminum electrode. The settling rate becomes very slow, as the solids settling enter compression region. It is also seen that the compression region for aluminum electrode-settled sludge is much denser than that of alum salt-settled sludge. Analysis of residue obtained after electrooxidation and chemical oxidation (Al metal and salt) at optimum $\mathrm{pH}$ is mentioned in Table 3.

\section{Filtration}

The filtration characteristics of the EC-generated sludge-slurry can be studied using either a plate and frame filter or a rotary vacuum filter [40]. Gravity filtration can also be used for generating experimental data. Gravity filtration can be considered as a constant pressure filtration by neglecting the effect of change in the hydrostatic head on the total pressure. The force balance for the gravity filtration using a filter paper on a Buchner funnel can be written as per MaCabe et al. [39]:

$$
\frac{\Delta t}{\Delta V}=\frac{\mu \alpha C}{A^{2} \Delta P} \cdot V+\frac{\mu}{A \Delta P} \cdot R_{\mathrm{m}}
$$

where $\Delta t$ is the time interval of filtration (s), $\Delta V$ is the filtrate volume collected up to that time interval $\left(\mathrm{m}^{3}\right), C$ is the solid concentration in the slurry $\left(\mathrm{kg} / \mathrm{m}^{3}\right), V$ is the total liquid filtrate volume collected up to the time interval $t\left(\mathrm{~m}^{3}\right), \mu$ is the viscosity of the liquid filtrate ( $\mathrm{Pa} \mathrm{s}), \Delta P$ is the pressure drop across the filter $=\rho g h(\mathrm{~Pa}), A$ is the filtration area $\left(\mathrm{m}^{2}\right)$, $R_{\mathrm{m}}$ is the resistance of the filter medium (/m), and $\alpha$ is the specific resistance to filtration, also called as SCR.

After recording the observations on the volume of the filtrate as a function of time, a plot $\Delta t / \Delta V$ may produce a straight line, which is shown in Fig. 7. The values of $R_{\mathrm{m}}$ $5.72 \times 10^{-12}$ and $\alpha 2.24 \times 10^{14}$ were observed for aluminum plate and $R_{\mathrm{m}} 1.56 \times 10^{-12}$ and $\alpha 1.30 \times 10^{-14}$ for aluminum salt at optimum $\mathrm{pH}$. It was calculated from the slope and the intercept, which is given in Table 4.
Table 3 Analysis of residue obtained after EC (Al plate) at different $\mathrm{pH}$

\begin{tabular}{llll}
\hline S. no. & Parameter/pH & Aluminum electrode & Alum salt \\
\hline 1 & Weight of residue $\left(\mathrm{kg} / \mathrm{m}^{3}\right)$ & 7.53 & 12.46 \\
2 & Color & Gray & Dark brown \\
3 & Nature & Tough to grind and flakey & $\begin{array}{c}\text { Easy to } \\
\text { grind and }\end{array}$ \\
& & & flakey \\
4 & Size $(\mathrm{mm})$ & $0.1-5$ & $1-5$ \\
5 & Approximated drying period (h) & 12 & 12 \\
6 & COD reduction $(\%)$ & 90 & 81 \\
7 & Color reduction $(\%)$ & 94 & 85 \\
8 & Optimum pH & 7 & 7 \\
9 & Loading & $178 \mathrm{~A} / \mathrm{m}^{3}$ & $50 \mathrm{mM}$ \\
\hline
\end{tabular}




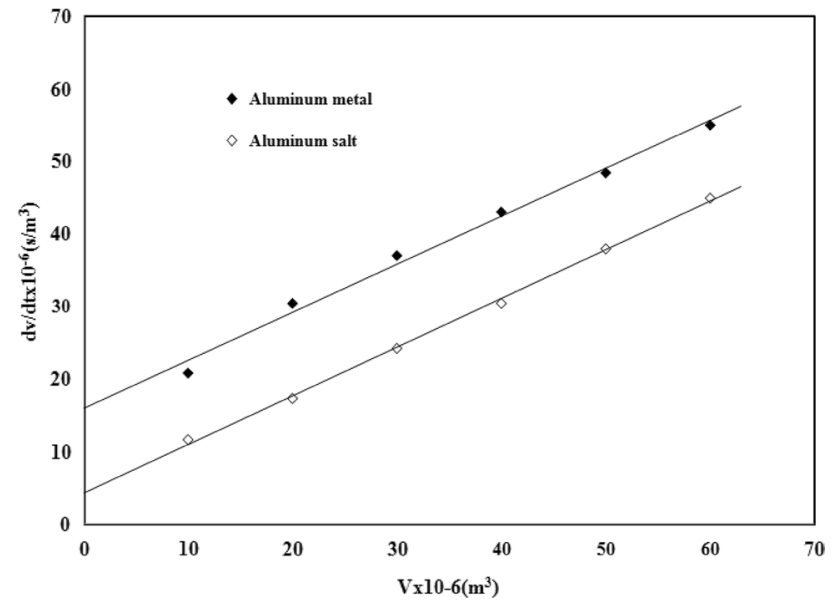

Fig. 7 Filterability of slurry at optimum $\mathrm{pH}$ and loading on electrocoagulation and chemical coagulation processes using aluminum electrode alum salt

\section{Thermal analysis}

The thermogravimetric analysis (TGA), differential thermogravimetric analysis (DTGA) and derivative thermal analysis (DTA) of scrum sludge and supernatant dried mass thermal characteristics were determined in the oxidizing (air) atmosphere at a heating rate of $10 \mathrm{~K} / \mathrm{min}$ with air flushing rate of $0.2 \mathrm{dm}^{3} / \mathrm{min}$. Figure 8 a shows the TG, DTA and DTG traces of the sugar industry aluminum metal-treated wastewater. In contrast to the TGA behavior of the precipitate, the wastewater TG traces show only about $2.6 \%$ decrease in weight up to $102{ }^{\circ} \mathrm{C}$. However, there has been a sudden drop in the weight of about $4.67 \%$ from 100 to $200{ }^{\circ} \mathrm{C}$ on account of vaporization of volatiles and moisture. The maximum rate of weight loss of $0.43 \mathrm{mg} / \mathrm{min}$ at $135{ }^{\circ} \mathrm{C}$ was observed with an exothermic heat evolution of $792 \mathrm{MJ} / \mathrm{kg}$ recorded at the peak temperature of $282{ }^{\circ} \mathrm{C}$. The rate of weight loss from $200{ }^{\circ} \mathrm{C}$ onwards was slow up to $400{ }^{\circ} \mathrm{C}$ losing weight of $9.87 \%$. Beyond $400{ }^{\circ} \mathrm{C}$, there has been a steady weight loss of about $3.4 \%$ up to $1011^{\circ} \mathrm{C}$, leaving the ash fraction of $79.44 \%$ as the residue. Figure $8 \mathrm{~b}$ shows the TG, DTA and DTG traces of the aluminum salt-treated wastewater under similar heating conditions. In contrast to the TGA behavior of the precipitate, the composite wastewater TG traces show only about $3.65 \%$ decrease in weight up to $100{ }^{\circ} \mathrm{C}$. However, there has been a sudden drop in the weight of about $8.79 \%$ from 100 to $202{ }^{\circ} \mathrm{C}$ on account of vaporization of volatiles and moisture. The maximum rate of weight loss of $0.41 \mathrm{mg} / \mathrm{min}$ at $112{ }^{\circ} \mathrm{C}$ was observed with an exothermic heat evolution of $102 \mathrm{MJ} / \mathrm{kg}$ recorded at the peak temperature of $332{ }^{\circ} \mathrm{C}$. The rate of weight loss from $202{ }^{\circ} \mathrm{C}$ onwards was slow up to $500{ }^{\circ} \mathrm{C}$ losing weight of $34.52 \%$. Beyond $500{ }^{\circ} \mathrm{C}$ there has been a steady weight loss of about $3.71 \%$ up to $1011^{\circ} \mathrm{C}$. It is found that the organics of the precipitate get oxidized leaving behind the ash fraction of $49.28 \%$ at $1011^{\circ} \mathrm{C}$ as a residue. The comparison of the two residues shows that the precipitate obtained after treatment gets oxidized at a higher temperature range than that of the sugar industry wastewater. This may be due to the presence of more stable compounds formed during electrochemical treatment in the presence of an aluminum electrode. The aluminum electrode material combined with colloidal of effluent and settled down in the bottom of the electrochemical reactor. Generally, thermal degradation data (TGA, DTA and DTGA) were used to analyze the kinetic models available in the literature [29, 47].

\section{Fourier infrared transform study}

The aluminum metal plate shows a very good reduction in COD (90\%) and color (94\%) for the treatment of SIWW. After treatment, the supernatants obtained were dried for the study of FITR. The IR spectral studies of waste samples (metal and salt treated) provide useful information on the presence of different functional groups. 10-15 mg of sample was dispersed in $200 \mathrm{mg}$ of spectroscopic-grade $\mathrm{KBr}$ to record the spectra. Scans were collected at a resolution of 4/ $\mathrm{cm}$. The wave numbers ranged from 4000 to $500 / \mathrm{cm}$. Sugar industry wastewater sample exhibits broadband covering the region $3150-2800 / \mathrm{cm}$ suggesting the presence of hydrogenbonded $v(\mathrm{OH})$ group. A broadband at $1500 / \mathrm{cm}$ due to $\delta(\mathrm{OH})$ further suggests the presence of the hydroxyl group, which is shown in Fig. 9a. A strong band at $1254 / \mathrm{cm}$ confirms the presence of sulfate group possibly attached with metal ions. In addition, the presence of conjugated carbon-carbon bond is indicated by the presence of a medium intensity band at $1462 / \mathrm{cm}$.

Dried sludge obtained after treatment with aluminum salt gave relatively sharper but still broader band at $3400 / \mathrm{cm}$. This is possibly due to the breaking of hydrogen bonds and the presence of either free hydroxyl or coordinated hydroxyl

Table 4 Filterability of the treated wastewater

\begin{tabular}{lllllllll}
\hline S. no. & Flocculants & Initial $\mathrm{pH}$ & Finial $\mathrm{pH}$ & $K_{\mathrm{p}} \times 10^{-12}\left(\mathrm{~s} / \mathrm{m}^{6}\right)$ & $\begin{array}{l}\beta \times 10^{-6}(\mathrm{~s} / \\
\left.\mathrm{m}^{3}\right)\end{array}$ & $C\left(\mathrm{~kg} / \mathrm{m}^{3}\right)$ & $\alpha \times 10^{-14}(\mathrm{~m} / \mathrm{kg})$ & $R_{\mathrm{m}} \times 10^{-12}$ \\
\hline 1 & Aluminum (metal) & 7 & 7.3 & 0.66 & 16 & 4.35 & 2.24 & 5.72 \\
2 & Aluminum (salt) & 7 & 6.5 & 0.67 & 4.366 & 6.58 & 1.30 & 1.56 \\
\hline
\end{tabular}


Fig. 8 Study of thermogravimetric analysis (TGA), differential thermogravimetric analysis (DTGA) and derivative thermal analysis (DTA) of SIWW. a Aluminum electrode $(\mathrm{SW}=10.36)$; $\mathbf{b}$ aluminum salttreated wastewater $(\mathrm{SW}=10.26)$
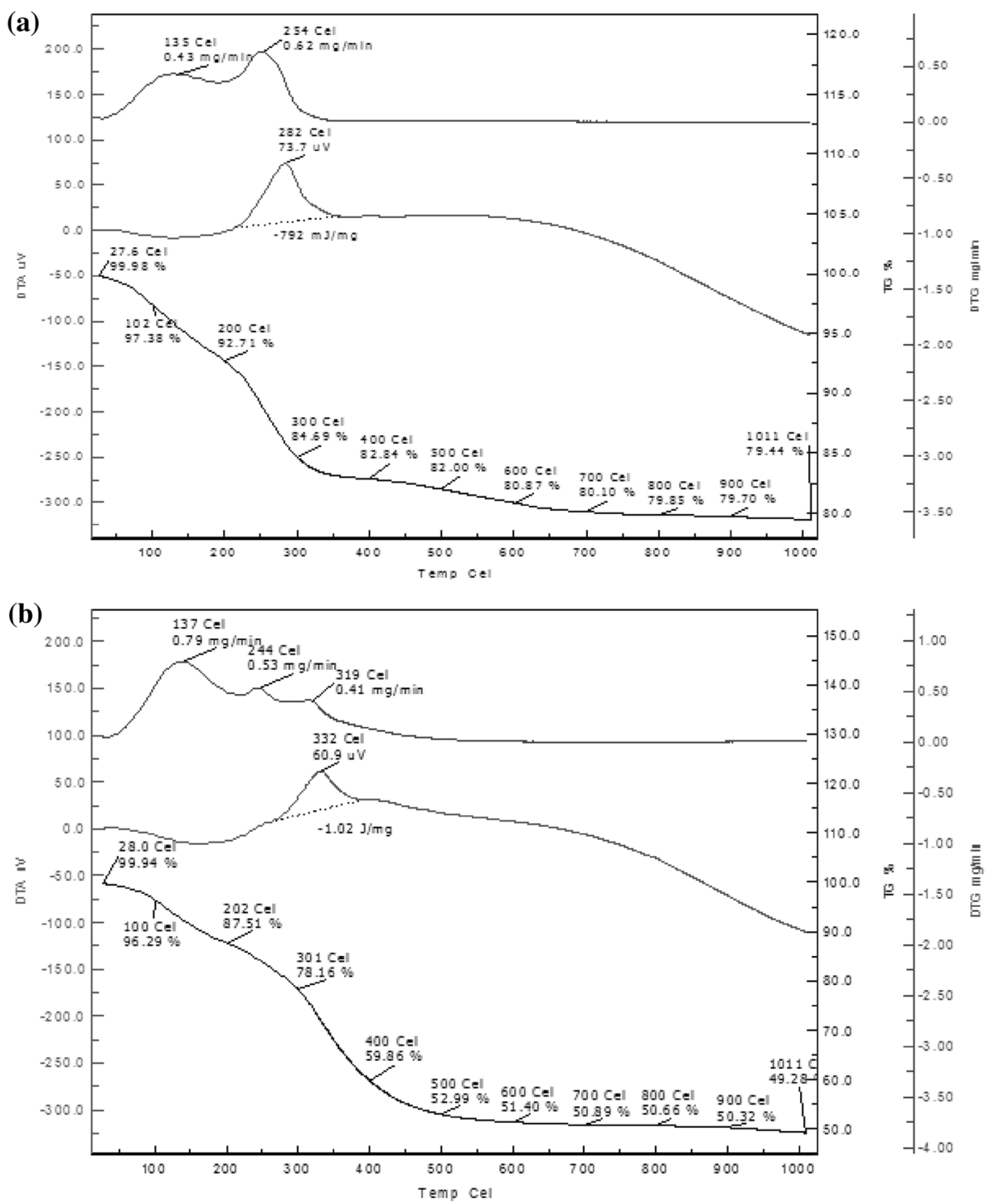

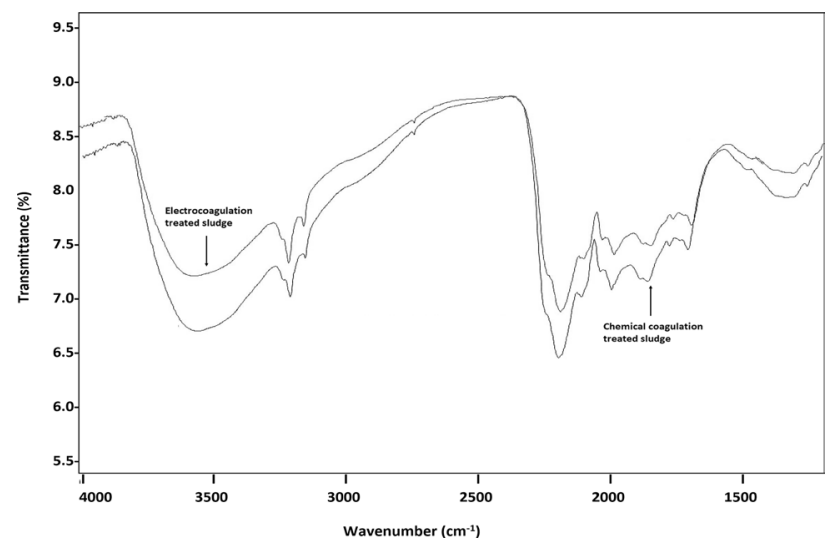

Fig. 9 FTIR spectra of sugar industry wastewater (dried) a before treatment and $\mathbf{b}$ after treatment with aluminum group. This also suggests the precipitation of the component bearing the hydroxyl group present in either complexed or free form. Absence of the band due to the sulfate group in this component indicates the removal of a sulfate group as a water-soluble component. The band at $986 / \mathrm{cm}$ is possibly due to the presence of metal oxide, which is further supported by the appearance of two bands at 596 and $480 / \mathrm{cm}$ due to $v(\mathrm{M}-\mathrm{O})$, which is shown in Fig. 9b. From this analysis, it was confirmed that aluminum forms complexes and precipitated at the bottom of the EC (Fig. 10).

\section{Scanning electron micrograph}

The scanning electron morphologies of metal- and salttreated sludge (dried) are shown in Fig. 8a, b. The sample that was treated with aluminum electrode has smaller particle sizes as compared to aluminum salt-treated sample. It indicates high porosity, inhomogeneous surface and 

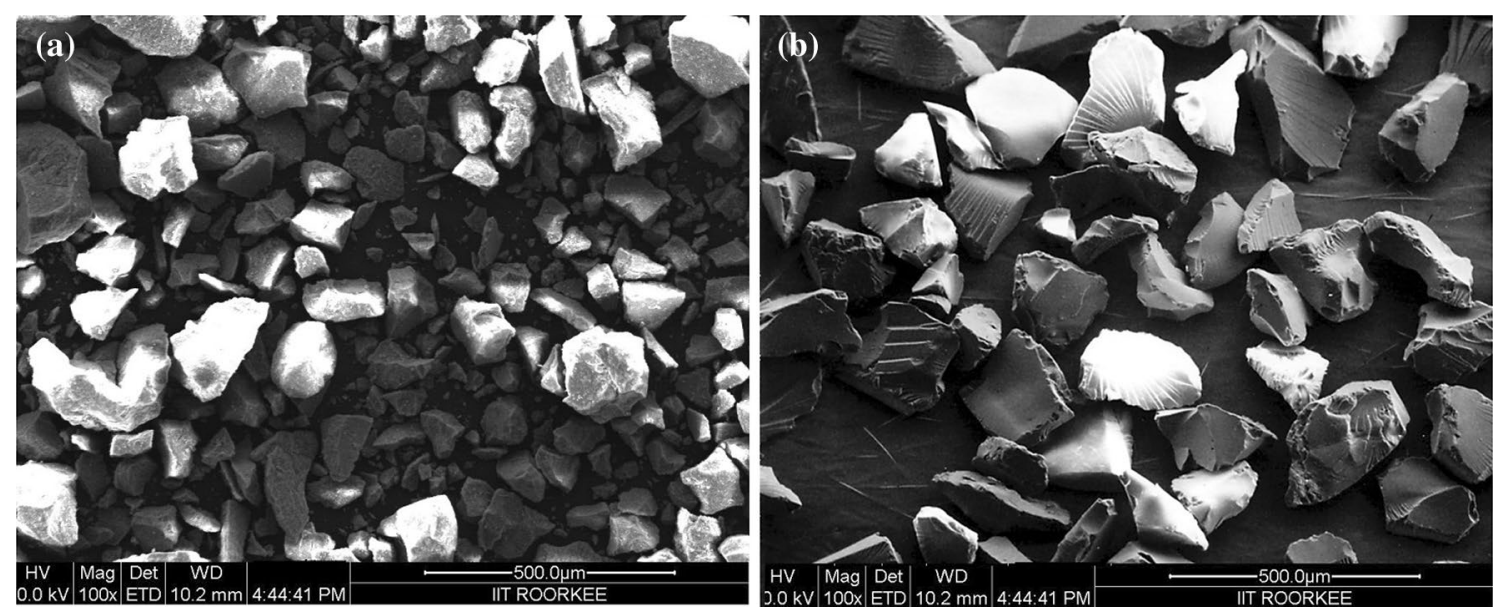

Fig. 10 Scanning electron micrograph of $\mathbf{a}$ untreated wastewater and $\mathbf{b}$ treated with aluminum

particles varying in shape. Alum-treated sample sludge has bigger particle size and is easy to grind. The electrooxidation eliminates various pollutants in the wastewater by oxidation; meanwhile, the aluminum compound particles are formed including pollutants. When the aluminum compound particles are agglomerated with each other, the organics may also be included in the aggregates [28].

\section{Cost estimation}

The cost of electrochemical systems is critical for its applicability to environmental problems and is normally not linked to the amount or nature of the pollutants, but is mainly attributed to the experimental conditions imposed. Electricity and electrodes can be considered to be the two major cost-involving components when applying ECT to wastewaters. Costs are also dependent on the wastewater conductivity, type and characteristics of wastewater, fluctuation in the global parameters, and the extent of the destruction, and the type of sludge desired as well. Although ECT treatment costs are high, a crude estimate of ECT of SIWW is made. The cost of energy for SIWW treatment and the cost of aluminum electrode material consumed were obtained from the experimental results (without the use of any additive) and the sum was taken as the operating cost:

Operating cost $=C_{\text {energy }}+C_{\text {electrode }}$.

\section{Energy consumption}

To treat the $1.4 \mathrm{dm}^{3}$ of SIWW, energy consumption is approximately $22.85 \mathrm{kWh} / \mathrm{h}$ at an energy price in the Indian market $=$ INR $8.75 / \mathrm{kWh}$.
Cost of energy per $\mathrm{m}^{3}$ of SIWW treated $=$ INR 8.75/ $\mathrm{kWh} \times 22.85 \mathrm{kWh}=\mathrm{INR} 199.93$.

2. Electrode consumption

Aluminum required per $\mathrm{m}^{3}$ of SIWW $=628 \mathrm{~g} / \mathrm{m}^{3}$.

Cost of aluminum sheets on bulk purchase (cleaning, cutting and placing $)=$ INR $84 / \mathrm{kg}$.

Cost of aluminum per $\mathrm{m}^{3}$ of SIWW treated $=0.628$ $\mathrm{kg} \times$ INR $84 / \mathrm{kg}=$ INR $52.75 / \mathrm{m}^{3}$.

Cost of energy + cost of electrode $=62.85+52.75=$ INR $252.68(\$=3.60)$ per $\mathrm{m}^{3}$ of SIWW treated.

\section{Conclusion}

To improve the industrial water use, water quantity and quality need to be considered. To avoid the unwanted release of contaminants to the environment, zero effluent discharge, which involves water reuse, recycling and regeneration, is the ultimate goal. It is concluded that aluminum compound has a good role in wastewater treatment, especially it shows high-performance addition with catalysis. Maximum 90\% (220 mg/L) COD and 94\% of color reduction were found with $05 \mathrm{M} \mathrm{NaCl}$ catalysis, $20 \mathrm{~mm}$ electrode distances, $178 \mathrm{~A} / \mathrm{m}^{3}$ current density at optimum pH 7 with electrochemical oxidation. It also shows $81 \%$ COD and $85 \%$ color reduction with $0.5 \mathrm{M}$ lime solution, $50 \mathrm{mM}$ mass loading, and $21{ }^{\circ} \mathrm{C}$ operating temperature at optimum pH 7 with chemical oxidation. Aluminum electrode shows good settling and filtration characteristics as compared to alum. The sludge (dried) generated after electrochemical treatment is small, flakey and grindable, which can be easily disposed. Otherwise, it can be used as fertilizer for agricultural crops. At last, electrocoagulation 
treatment is found to be more efficient as compared to chemical coagulation treatment.

Open Access This article is distributed under the terms of the Creative Commons Attribution 4.0 International License (http://creativeco mmons.org/licenses/by/4.0/), which permits unrestricted use, distribution, and reproduction in any medium, provided you give appropriate credit to the original author(s) and the source, provide a link to the Creative Commons license, and indicate if changes were made.

\section{References}

1. Ali I, Al-Othman ZA, Alharbi OM (2016) Uptake of pantoprazole drug residue from water using novel synthesized composite iron nano adsorbent. J Mol Liq 218:465-472

2. Ali I, AL-Othman ZA, Alwarthan A (2016) Green synthesis of functionalized iron nano particles and molecular liquid phase adsorption of ametryn from water. J Mol Liq 221:1168-1174

3. Ali I, AL-Othman ZA, Alwarthan A (2016) Molecular uptake of congo red dye from water on iron composite nano particles. J Mol Liq 224:171-176

4. Ali I, Al-Othman ZA, Al-Warthan A (2016) Removal of secbumeton herbicide from water on composite nanoadsorbent. Desalinat Water Treat 57(22):10409-10421

5. Ali I, Alothman ZA, Al-Warthan A (2016) Sorption, kinetics and thermodynamics studies of atrazine herbicide removal from water using iron nano-composite material. Int J Environ Sci Technol 13(2):733-742

6. Ali I, AL-Othman ZA, Alwarthan A (2016) Synthesis of composite iron nano adsorbent and removal of ibuprofen drug residue from water. J Mol Liq 219:858-864

7. Ali I, Asim M, Khan TA (2013) Arsenite removal from water by electro-coagulation on zinc-zinc and copper-copper electrodes. Int J Environ Sci Technol 10(2):377-384

8. Ali I, Gupta VK, Khan TA, Asim M (2012) Removal of arsenate from aqueous solution by electro-coagulation method using AlFe electrodes. Int J Electrochem Sci 7:1898-1907

9. Ali I, Khan TA, Asim M (2012) Removal of arsenate from groundwater by electrocoagulation method. Environ Sci Pollut Res 19(5):1668-1676

10. Andersen DO, Alberts JJ, Takacs M (2000) Nature of natural organic matter (NOM) in acidified and limed surface waters. Water Res 34(1):266-278

11. Bajare D, Korjakins A, Kazjonovs J, Rozenstrauha I (2012) Pore structure of lightweight clay aggregate incorporate with non-metallic products coming from aluminum scrap recycling industry. J Eur Ceram Soc 32:141-148

12. Bayramoglu M, Eyvaz M, Kobya M (2007) Treatment of the textile wastewater by electrocoagulation: economic evaluation. Chem Eng J 128:155-161

13. Bazrafshan E, Moein H, Mostafapour FK, Nakhaie S (2013) Application of electrocoagulation process for dairy wastewater treatment. J Chem. https://doi.org/10.1155/2013/640139

14. Bradford MM (1976) A rapid and sensitive method for the quantitation of microgram quantities of protein utilizing the principle of protein-dye binding. Annual Biochemical 72:248-254

15. Calder GV, Stark TD (2010) Aluminum reactions and problems in municipal solid waste landfills. Pract Period Hazard Toxicol Radioact Waste Manag 14:258-265

16. Can OT, Kobya M, Demirbas E, Bayramoglu M (2006) Treatment of the textile wastewater by combined electrocoagulation. Chemosphere 62:181-187
17. Chen G (2004) Electrochemical technologies in wastewater treatment. Sep Purif Technol 38:11-41

18. Chen H, Ling M, Hencz L, Ling HY, Li G, Lin Z, Liu G, Zhang $S$ (2018) Exploring chemical, mechanical, and electrical functionalities of binders for advanced energy-storage devices. Chem Rev 118(18):8936-8982

19. Dash B, Das BR, Tripathy BC, Bhattacharya IN, Das SC (2008) Acid dissolution of alumina from waste aluminum dross. Hydrometallurgy 92(2008):48-53

20. Dehghani M, Seresht SS, Hashemi H (2014) Treatment of hospital wastewater by electrocoagulation using aluminum and iron electrodes. Int J Environ Health Eng 3:15-29

21. Demirbas E, Kobya M (2017) Operating cost and treatment of metalworking fluid wastewater by chemical coagulation and electrocoagulation processes. Process Saf Environ Prot 105:79-90

22. Dennett KE, Amirtharajah A, Moran TF, Gould JP (1996) Coagulation: its effect on organic matter. J AWWA 88(4):129-142

23. Dermentzis K, Christoforidis K, Valsamidou E (2011) Removal of nickel, copper, zinc and chromium from synthetic and industrial wastewater by electrocoagulation. Int J Environ Sci 1(5):697-710

24. Deshpande AM, Satyanarayan S (2011) Toxicity evaluation of through fish bioassay raw bulk drug industry wastewater after electrochemical treatment. Iran J Environ Health Sci Eng 8(4):373-380

25. Donini J, Kan J, Szynkarczuk J, Hassan T, Kar K (1994) The operating cost of electrocoagulation. Can J Chem Eng 72:1007-1012

26. Drogui P, Asselin M, Brar SK, Benmoussa H, Blais JF (2008) Electrochemical removal of pollutants from agro-industry wastewaters. Sep Purif Technol 61:301-310

27. Engelhardt TL (2010) Coagulation, flocculation and clarification of drinking water, report

28. Feng L, Zhang H, Wang Z, Liu Y (2014) Superhydrophobic aluminum alloy surface: fabrication, structure, and corrosion resistance. Colloids Surf A 441:319-325

29. Gangavati PB, Safi MJ, Singh A, Prasad B, Mishra IM (2005) Pyrolysis and thermal oxidation kinetics of sugar mill press mud. Thermochim Acta 428(1-2):63-70

30. Ghosh D, Medhi CR, Solanki H, Purkait MK (2008) Decolorization of crystal violet solution by electrocoagulation. J Environ Protect Sci 2:25-35

31. Giwa SO, Ertunc S, Alpbaz M, Hapoglu H (2012) Electrocoagulation treatment of turbid petrochemical wastewater. Int J Adv Sci Technol 5(5):23-91

32. Hakizimana JN, Gourich B, Chafi M, Stiriba Y, Vial C, Drogui P, Naja J (2017) Electrocoagulation process in water treatment: a review of electrocoagulation modeling approaches. Desalination 404:1-21

33. Holt P, Barton G, Mitchell C (1999) Electrocoagulation as a wastewater treatment the third annual Australian Environmental Engineering Research Event, 23-26 November Castlemaine, Victoria

34. Holt PK, Barton GW, Mitchell CA (2005) The future for electrocoagulation as a localised water treatment technology. Chemosphere 59:355-367

35. Jiaqian J (1998) An anodic passivation of electrocoagulator in the process of water treatment. Water Treat 3:344-352

36. Parmar KA, Prajapati S, Patel R, Dabhi Y (2011) Effective use of ferrous sulfate and alum as a coagulant in treatment of dairy industry wastewater. ARPN J Eng Appl Sci 6(9):42-45

37. Kumar P, Teng TT, Chand S, Kailas L (2011) Wastewater, treatment of paper and pulp mill effluent by coagulation. Int J Civ Environ Eng 3:3 
38. Kushwaha JP (2015) A review on sugar industry wastewater: sources, treatment technologies, and reuse. Desalinat Water Treat 53(2):309-318

39. MaCabe WL, Smith JC, Harriot P (2001) Unit operations of chemical engineering, 6th edn. McGraw-Hill, New York

40. Mahesh S, Prasad B, Mall ID, Mishra IM (2006) Electrochemical degradation of pulp and paper mill wastewater. Part 2. Characterization and analysis of sludge. Ind Eng Chem Res 45(16):5766-5774

41. Moussa DT, El-Naas MH, Nasser M, Al-Marri MJ (2017) A comprehensive review of electrocoagulation for water treatment: potentials and challenges. J Environ Manage 186:24-41

42. Nasrullaha M, Singh L, Wahida ZA (2012) Treatment of sewage by electrocoagulation and the effect of high current density. Energy Environ Eng J 1(1):27-31

43. Prakash NB, Sockan V, Jayakaran P (2014) Waste water treatment by coagulation and flocculation. Int J Eng Sci Innovat Technol $3(2): 479-484$

44. Ravina L (1994) Coagulation and flocculation. Zeta-Meter, Inc. Staunton, Virginia. http://www.zeta-meter.com

45. Richardson JF, Harker JH, Backhurst JR (2003) Coulson and Richardson's chemical engineering, particle technology and separation process, 5th edn. Butterworth-Heinemann, Woburn

46. Sabur MM, Khan AA, Safiullah S (2012) Treatment of textile wastewater by coagulation precipitation method. J Sci Res 4(3):623-633

47. Safi MJ, Mishra IM, Prasad B (2004) Global degradation kinetics of pine needles in air. Thermochim Acta 155:412

48. Sahu OP, Chaudhari PK (2014) Physicochemical treatment of sugar industry wastewater: coagulation processes. Environ Qual Manag Summer 23:49-69

49. Sahu O, Mazumdar B, Chaudhari PK (2014) Treatment of wastewater by electrocoagulation: a review. Environ Sci Pollut Res 21(4):2397-2413

50. Sahu O, Rao DG, Gopal R, Tiwari A, Pal D (2017) Treatment of wastewater from sugarcane process industry by electrochemical and chemical process: aluminum (metal and salt). J Water Process Eng 17:50-62

51. Sahu OP, Chaudhari PK (2013) Review on chemical treatment of industrial waste water. J Appl Sci Environ Manag 17(2):241-257

52. Samadi MT, Saghi MH, Rahmani A, Hasanvand J, Rahimi S, Syboney MS (2010) Hamadan landfill leachate treatment by coagulation-flocculation process. Iran J Environ Health Sci Eng 7(3):253-258

53. Song S, Yao J, He Z, Qiu J, Chen J (2008) Effect of operational parameters on the decolorization of C.I. reactive blue 19 in aqueous solution by ozone-enhanced electrocoagulation. J Hazard Mater 152:204-210

54. Teh CY, Budiman PM, Shak KPY, Wu TY (2016) Recent advancement of coagulation-flocculation and its application in wastewater treatment. Ind Eng Chem Res 55(16):4363-4389

55. Totten E, MacKenzie DS (2003) Handbook of aluminum: physical metallurgy and processes, vol 1. Marcel Dekker Inc, New York

56. Tsakiridis PE (2012) Aluminium salt slag characterization and utilization-a review. J Hazard Mater 217-218:1-10

57. Upadhyay AP, Mistry NJ (2012) Feasibility of combined Fenton and coagulation method for the treatment of pesticides waste water. Int J Eng Res Technol 1(3):115-125

58. Vogel AI (1958) A text book of quantitative inorganic analysis, 3rd edn. Longman, London

59. Xu Y, Chen T, Cui F, Shi W (2016) Effect of reused alum-humicflocs on coagulation performance and floc characteristics formed by aluminum salt coagulants in humic-acid water. Chem Eng J 287:225-232

60. Zonoozi MH, Moghaddam MRA, Arami M (2008) Removal of acid red 398 dye from aqueous solutions by coagulation/flocculation process. Environ Eng Manag J 7(6):695-699

Publisher's Note Springer Nature remains neutral with regard to jurisdictional claims in published maps and institutional affiliations. 